\title{
PENGARUH RASIO-RASIO KEUANGAN DAN KANTOR AKUNTAN PUBLIK TERHADAP AUDIT DELAY
}

\author{
Afif Amrulah Pugel ${ }^{1}$, Andreas Vernando ${ }^{2 *}$ \\ 1,2 Universitas Ahmad Dahlan, Yogyakarta, Indonesia \\ *e-mail: andreas.vernando@act.uad.ac.id
}

\begin{abstract}
DiPublikasi: 01/07/2021
https://doi.org/10.22225/kr.13.1.2021.147-153

Abstract

This study aims at examining the effect of financial ratios and public accounting firms on audit delay in trading, service and investment firms listed on the Indonesia Stock Exchange (IDX). This research is based on the phenomenon that firms in the trade, service and investment industries are the companies that reap the most sanctions by the IDX. This study hypothesizes that financial ratios and public accounting firm are the factors causing the delay in the issuance of audited financial statements (audit delay). Using 108 observations of trading, service and investment firms listed on the IDX, this study finds that profitability has an effect on audit delay. However, this study does not find that firm size, KAP size, solvability, and losses have an effect on audit delay.

Keywords: Audit delay, financial ratios, and public accounting firm
\end{abstract}

\begin{abstract}
Abstrak
Penelitian ini bertujuan untuk menguji pengaruh rasio-rasio keuangan dan Kantor Akuntan Publik (KAP) terhadap audit delay di perusahaan perdagangan, jasa dan investasi yang tercatat di Bursa Efek Indonesia (BEI). Penelitian ini didasari oleh fenomena bahwa perusahaan di industri perdagangan, jasa dan investasi merupakan perusahaan yang terbanyak menerima sanksi oleh BEI. Penelitian ini berhipotesis bahwa rasio-rasio keuangan dan Kantor Akuntan Publik (KAP) merupakan faktor menyebabkan terjadinya keterlambatan penerbitan laporan keuangan (audit delay). Dengan menggunakan 108 observasi dari perusahaan perdagangan, jasa dan investasi yang terdaftar di BEI. penelitian ini menemukan bahwa profitabilitas berpengaruh terhadap audit delay. Akan tetapi, penelitian ini tidak menemukan bahwa ukuran perusahaan, ukuran KAP, solvabilitas, dan rugi perusahaan berpengaruh terhadap audit delay.
\end{abstract}

Kata Kunci : Audit delay, rasio-rasio keuangan, dan kantor akuntan publik

\section{PENDAhuluan}

Baru-baru ini Bursa Efek Indonesia (BEI) memberikan sanksi tertulis dan denda sebesar 50 juta rupiah kepada 24 perusahaan yang terlambat dalam penyampaian laporan keuangan (CNBC, 2019). Banyaknya perusahaan yang terkena sanksi dari Bursa Efek Indonesia menunjukkan perusahaan lalai dalam hal ketepatan laporan keuangan. Dari 24 perusahaan tersebut, terdapat 8 perusahaan di industri perdagangan, jasa dan investasi. Hal ini menjadikan sektor perdagangan, jasa dan investasi menjadi perusahaan yang terbanyak dalam keterlambatan penyampaian laporan keuangan. Oleh karena itu, penelitian ini bertujuan untuk menguji faktor-faktor yang mempengaruhi audit delay pada perusahaan vang tercatat di Bursa Efek Indonesia (BEI).
Regulasi terkait waktu penyampaian laporan keuangan diatur di dalam peraturan Otoritas Jasa Keuangan No. 29/POJK.04/2016 tentang penyampaian laporan tahunan emiten atau perusahaan publik. Regulasi tersebut menetapkan bahwa laporan tahunan diterbitkan paling lambat bulan ke-empat setelah tanggal neraca atau 31 Desember. Keterlambatan penerbitan laporan keuangan atau audit delay akan berdampak pada terlambatnya pengambilan keputusan investasi. Jika auditor membutuhkan waktu lebih lama untuk menyelesaikan pekerjaannya maka hal ini akan mengisyaratkan terdapat masalah dalam laporan keuangan perusahaan.

Jangka waktu auditor untuk mengaudit suatu laporan keuangan perusahaan dapat 
ditinjau dari adanya perbedaan waktu antara tanggal laporan keuangan dengan tanggal opini audit. Laporan audit yang diselesaikan tepat waktu akan memberikan manfaat yang lebih besar terdapat keputusan investasi.

\section{TINJAUAN PUSTAKA}

\section{Ukuran Perusahaan dan Audit Delay}

Menurut Fiatmoko dan Anisykurlillah (2015), ukuran perusahaan berkemungkinan mempengaruhi audit delay. Perusahaan yang lebih besar, lebih memiliki sumber daya dan sistem yang baik, termasuk sistem pengendalian internal baik. Karena perusahaan yang lebih besar memiliki sistem pengendalian internal yang baik, auditor akan lebih mudah dan cepat dalam melakukan proses audit.

Faktor lain yang menjelaskan mengapa ukuran perusahaan berpengaruh terhadap audit delay yaitu besarnya insentif yang diberikan oleh manajemen perusahaan untuk mengurangi audit delay karena perusahaan yang lebih besar cenderung lebih banyak dimonitor oleh analis keuangan dan partisipan pasar. Argumen ini didukung oleh hasil penelitian terdahulu (Amani, F. A., \& Waluyo, 2016) yang melaporkan bahwa ukuran perusahaan berpengaruh terhadap audit delay. Dari argumen dan hasil penelitian terdahulu, maka hipotesis yang diajukan yakni:

H1: Ukuran perusahaan berpengaruh terhadap audit delay.

\section{Ukuran KAP Terhadap Audit Delay}

Menurut Apriyani (2015), ukuran KAP berkemungkinan berpengaruh terhadap audit delay. Argumentasinya adalah KAP Big Four memiliki sumber daya manusia yang terampil, memiliki sistem dan alat-alat audit yang lebih canggih. Selain itu, auditor di KAP dengan reputasi yang baik mendapatkan insentif yang lebih tinggi untuk bekerja lebih cepat dan profesional untuk tetap mempertahankan reputasinya sehingga dapat menyelesaikan proses audit tepat waktu. Penjelasan ini juga didukung oleh hasil penelitian terdahulu (Pratama, 2015; Trisnawati \& Charistine, 2008) yang menyediakan bukti empiris bahwa ukuran KAP berpengaruh terhadap audit delay. Dari penjelasan dan hasil penelitian terdahulu, maka hipotesis yang diajukan yaitu:

H2: Ukuran KAP berpengaruh terhadap audit delay.
Penelitian ini menduga ukuran perusahaan, ukuran KAP, solvabilitas, profitabilitas, dan rugi perusahaan merupakan penyebab atas terjadinya audit delay.

\section{Solvabilitas dan Audit Delay}

Menurut Syah (2017), perusahaan dengan tingkat solvabilitas yang tinggi diprediksi akan mengalami audit delay. Rasio solvabilitas yang tinggi merupakan penyebab keterlambatan penyampaian laporan audit karena proporsi hutang yang besar terhadap total aktiva akan meningkatkan potensi menurunkan laba atau bahkan rugi karena beban bunga yang besar dibayar oleh perusahaan. Selain itu, solvabilitas yang tinggi menunjukkan bahwa pendaan dari kreditor cukup tinggi di perusahaan klien. Dengan demikian, jika perusahaan mengalami permasalahan keuangan, para kreditor akan menuntut para pihak termasuk auditor sehingga auditor akan lebih meningkatkan kewasapadaan dan kehati-hatian jika mengaudit klien yang jumlah utang yang relatif besar sehingga akan meningkatkan kemungkinan keterlambatan laporan audit.

Surbakti dan Aginta (2019), dan Trisnawati dan Charistine (2008) menemukan bahwa solvabilitas berpengaruh terhadap audit delay. Dari argumen dan hasil penelitian terdahulu, maka hipotesis yang diajukan yakni:

H3: Solvabilitas berpengaruh terhadap audit delay.

\section{Profitabilitas dan Audit Delay}

Menurut Saemargani dan Mustikawati (2019), profitabilitas berkemungkinan berpengaruh terhadap audit delay. Profitabilitas merupakan good news yang merupakan dasar mengapa perusahaan berusaha untuk mempercepat penerbitan laporan audit. Hal ini juga didukung oleh hasil penelitian dari Amani dan Waluyo (2016), serta Melati dan Sulistyawati (2016) yang menemukan bahwa profitabilitas berpengaruh terhadap audit delay. Dari penjelasan dan hasil penelitian terdahulu, maka hipotesis yang diajukan yakni:

H4: Profitabilitas berpengaruh terhadap audit delay.

\section{Rugi Perusahaan dan Audit Delay}


Auditor akan meningkatkan kewaspadaan jika perusahaan mengalami kerugian. Hal ini karena auditor berpotensi tersangkut litigasi di masa mendatang.

Jika perusahaan mengalami kerugian karena menanggung beban bunga yang besar, auditor akan meningkatkan kewaspadaannya terhadap asumsi going concern yang berkemungkinan dilanggar. Untuk memastikan dugaan asumsi going concern tidak dilanggar, maka auditor akan berdiskusi dengan cukup komprehensif untuk menanyakan strategi untuk mengatasi hal tersebut. Dalam rangka untuk menghindari kesalahan dalam pemberian opini audit sehingga mengakibatkan keterlambatan pada penyajian laporan keuangan. Kartika (2009) dan Juanita dan Satwiko (2012) menemukan bahwa laba/rugi berpengaruh terhadap audit delay. Dari penjelasan dan hasil penelitian terdahulu, maka hipotesis yang diajukan yakni:

H5: Rugi perusahaan berpengaruh terhadap audit delay.

\section{Gambar 1.}

\section{Rerangka Model Penelitian}

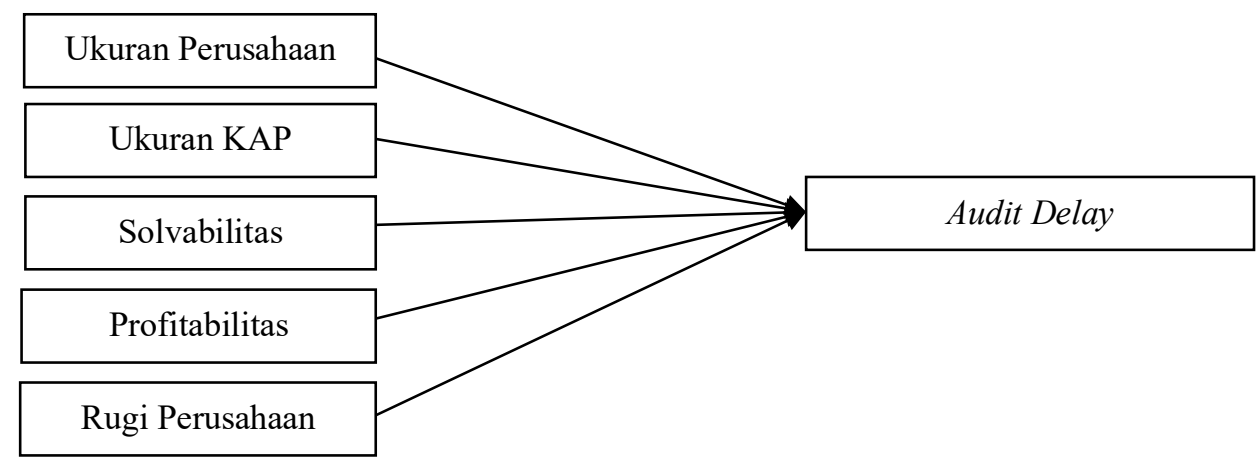

\section{METODE PENELITIAN}

\section{Sampel}

Sampel dalam penelitian ini mencakup semua perusahaan perdagangan, jasa, dan investasi yang terdaftar di Bursa Efek Indonesia pada tahun 2017-2018. Metode pengambilan sampel dalam penelitian ini menggunakan metode purposive sampling. Kriteria pengambilan sampel dalam penelitian ini adalah perusahaan yang mempublikasikan laporan keuangan yang sudah diaudit lengkap secara berturut-turut pada tahun 2017 sampai dengan tahun 2018 dan laporan keuangan perusahaan yang tutup buku pada tanggal 31 Desember.

\section{Alat Analisis}

Penelitian ini menggunakan analisis regresi linier berganda. Sebelum menguji regresi, penelitian ini terlebih dahulu menguji asumsi klasik, uji normalitas, uji heteroskedastisitas, uji autokorelasi, dan uji multikolinieritas. Data di dalam penelitian ini tidak melanggar uji asumsi klasik. Lebih lanjut, persamaan regresi sebagai berikut:
Delay $=a+b_{1}$ Size $+b_{2}$ KAP $+b_{3}$ Solvabilitas +

$\mathrm{b}_{4}$ Profit $+\mathrm{b}_{5}$ Rugi $+\mathrm{e}$

Keterangan:

$\mathrm{a}=$ Konstanta

$\mathrm{b}_{1}-\mathrm{b}_{5}=$ Koefisien

Delay= Audit Delay

Size $=$ Ukuran Perusahaan

$\mathrm{KAP}=$ Ukuran KAP

Solvabilitas $=$ Solvabilitas

Profit $=$ Profitabilitas

Rugi= Rugi Perusahaan

$\mathrm{e}=$ error

\section{Pengukuran Variabel}

Audit Delay

Audit delay adalah lamanya selisih waktu antara tanggal penyelesaian proses audit dengan tanggal penerbitan laporan keuangan tahunan perusahaan. Audit delay diukur berdasarkan lamanya hari yang dibutuhkan auditor independen menyelesaikan laporannya atas audit laporan keuangan tahunan

Jurnal KRISNA: Kumpulan Riset Akuntansi Volume 11, Nomor 22020 CC-BY-SA 4.0 License

Page 149 
perusahaan, yang dihitung sejak tanggal tahun tutup buku perusahaan yaitu per 31 Desember sampai tanggal yang tertera pada laporan audit independen (Saemargani dan Indah, 2015). Audit delay pada penelitian ini dihitung berdasarkan selisih waktu antara tanggal penyelesaian laporan keuangan dan tanggal laporan auditor.

\section{Ukuran Perusahaan}

Ukuran perusahaan adalah besar kecilnya suatu perusahaan. Hal ini bisa diukur dari total aktiva, total penjualan, jumlah tenaga kerja. Penelitian ini menggunakan total aset dengan log natural total aset (Saemargani \& Mustikawati, 2015).

\section{Ukuran KAP}

Ukuran KAP di dalam penelitian ini menggunakan variabel dummy yaitu dengan memberikan kode 1 untuk KAP yang berafiliasi dengan KAP big four, dan kode 0 jika tidak (Trisnawati \& Charistine, 2008).

\section{HASIL DAN PEMBAHASAN}

Dengan menggunakan teknik kriteria penyampelan, penelitian ini berhasil memperoleh sejumlah 118 observasi dari

\section{Solvabilitas}

Rasio solvabilitas adalah rasio yang menjadi tolak ukur tingkat pembiayaan utang menggunakan aktiva perusahaan (Kasmir, 2008). Dalam penelitian ini, perhitungan rasio solvabilitas sebagai berikut:

DER $=($ Total Hutang $) /($ Total Aktiva $)$

\section{Profitabilitas}

Profitabilitas merupakan salah satu ukuran dari kinerja perusahaan. Penelitian ini mengukur variabel profitabilitas sebagai berikut (Kasmir, 2008):

$\mathrm{ROA}=($ Laba Bersih $) /($ Total Aset $) \times 100 \%$

\section{Rugi Perusahaan}

Variabel rugi perusahaan dalam penelitian ini diukur dengan dummy yaitu untuk perusahaan yang mengalami rugi diberi kode 1 dan 0 jika tidak (Regilia, 2018).

\section{Tabel 1}

Statistik Deskriptif

\begin{tabular}{llrrrr}
\hline \hline Variabel & $\mathrm{N}$ & Min. & Maks. & Rerata & Dev. Std. \\
Ukuran Perusahaan & 118 & 11,39 & 24,75 & 21,2219 & 2,35763 \\
Ukuran KAP & 118 & 0 & 1 & 0,36 & 0,483 \\
Solvabilitas & 118 & 0,07 & 1,74 & 0,5025 & 0,23729 \\
Profitabilitas & 118 & $-0,31$ & 0,35 & 0,0294 & 0,08007 \\
Rugi Perusahaan & 118 & 0 & 1 & 0,20 & 0,404 \\
Audit Delay & 118 & 45 & 119 & 80,04 & 10,409 \\
\hline \hline
\end{tabular}

Sumber: Data diolah peneliti tahun 2020

Tabel 1 menunjukkan nilai rata-rata ukuran perusahaan sebesar 21,22 dengan nilai tertinggi sebesar 24,75 sedangkan nilai ukuran perusahaan terendah sebesar 11,39. Lebih lanjut, nilai minimum untuk variabel solvabilitas adalah 0,07 dan nilai maksimumnya sebesar 1,74 . Rata-rata variabel solvabilitas adalah 0,5025 yang menunjukkan bahwa rata-rata setengah dari total aset perusahaan didanai oleh utang.

Nilai minimum variabel profitabilitas (ROA) adalah sebesar $-0,31$ dan nilai maksimumnya sebesar 0,35 . Nilai rata-rata variabel profitabilitas adalah 0,0294, mengindikasikan bahwa rata-rata perusahaan yang menjadi sampel mengalami keuntungan.

Nilai audit delay adalah antara 45 hari sampai 119 hari dengan rata-rata 80,04 hari. Hal ini mengindikasikan bahwa perusahaan menerbitkan laporan keuangan auditannya paling cepat adalah 45 hari setelah tanggal tutup buku, dan paling lambat 119 hari setelah tanggal tutup buku. 
Tabel 2

Hasil Analisis Regresi Linier Berganda

\begin{tabular}{llll}
\hline \hline Delay $=\mathrm{a}+\mathrm{b}$ 1Size + b2KAP + b3 Solvabilitas + b4Profit + b5Rugi $+\mathrm{e}$ & \\
\hline Variabel & Koefisien & t-Statistik & Signifikansi \\
\hline Konstanta & 77,663 & 8,883 & 0,000 \\
Ukuran Perusahaan & 0,207 & 0,529 & 0,598 \\
Ukuran KAP & $-2,796$ & $-1,467$ & 0,145 \\
Solvabilitas & $-1,760$ & $-0,418$ & 0,677 \\
Profitabilitas & $-30,975$ & $-2,058$ & 0,042 \\
Rugi Perusahaan & 3,975 & 1,363 & 0,175 \\
Observasi & 118 & & \\
Adj. R Square & 0,106 & & \\
\hline \hline
\end{tabular}

Sumber: Data diolah peneliti tahun 2020

Tabel 2 menunjukkan hasil pengujian dengan metode regresi linier berganda untuk menguji pengaruh variabel-variabel independen (ukuran perusahaan, ukuran KAP, solvabilitas, profitabilitas, laba atau rugi) terhadap variabel dependen (audit delay)

Berdasarkan hasil analisis regresi linear berganda dalam Tabel 2 menunjukan bahwa nilai signifikansi variabel ukuran perusahaan sebesar 0.598. Nilai tersebut lebih besar dari alpha (0,05), maka H1 ditolak. Hasil penelitian menunjukan bahwa variabel ukuran perusahaan tidak berpengaruh terhadap audit delay.

Hasil penelitian menunjukkan bahwa ukuran perusahaan tidak berpengaruh terhadap audit delay. Hal ini mungkin disebabkan oleh perusahaan dengan total aset menengah maupun besar memiliki internal kontrol yang baik serta memiliki kemampuan untuk menekan auditornya agar dapat menyelesaikan tugas audit laporan keuangan perusahaan secara tepat waktu agar tidak terkena sanksi dari BEI. Hasil penelitian ini sependapat dengan hasil penelitian Saemargani dan Mustikawati (2015) dan Haryani dan Wiratmaja (2014) dan Surbakti dan Aginta (2019) yang menunjukkan bahwa ukuran perusahaan tidak berpengaruh pada audit delay.

Berdasarkan hasil analisis regresi linear berganda dalam Tabel 2 menunjukan bahwa nilai signifikansi variabel ukuran KAP sebesar 0.145 . Nilai tersebut lebih besar dari alpha $(0,05)$, maka H2 ditolak. Hasil penelitian menunjukan bahwa variabel ukuran KAP tidak berpengaruh terhadap audit delay.

Hasil penelitian menunjukkan bahwa ukuran KAP tidak berpengaruh terhadap audit delay. Hal ini diperkirakan KAP big four dan KAP non-big four mengacu pada standar yang sama sesuai dengan standar profesional sehingga dapat menghasilkan kualitas audit yang baik. Hasil penelitian ini sejalan dengan penelitian terdahulu (Fiatmoko \& Anisykurlillah, 2015; Juanita \& Satwiko, 2012; Melati \& Sulistyawati, 2016; Saemargani \& Mustikawati, 2015) yang menemukan bahwa ukuran KAP tidak berpengaruh terhadap audit delay.

Berdasarkan hasil analisis regresi linear berganda dalam Tabel 2 menunjukan bahwa nilai signifikansi variabel solvabilitas sebesar 0.677 . Nilai tersebut lebih besar dari alpha $(0,05)$, maka H3 ditolak. Hasil penelitian menunjukan bahwa variabel solvabilitas tidak berpengaruh terhadap audit delay.

Hasil penelitian menunjukkan bahwa solvabilitas tidak berpengaruh terhadap audit delay. Hal tersebut dimungkinkan karena auditor menjaga reputasinya dengan menerbitkan laporan audit tepat waktu tanpa mempertimbangkan apakah perusahaan memiliki laba atau rugi. Hasil penelitian ini sesuai dengan penelitian terdahulu (Juanita \& Satwiko, 2012; Melati \& Sulistyawati, 2016; Saemargani \& Mustikawati, 2015) yang menemukan solvabilitas tidak memiliki pengaruh terhadap audit delay.

Berdasarkan hasil analisis regresi linear herganda dalam Tahel 2 menuniukan hahwa 
nilai signifikansi variabel profitabilitas sebesar 0.042 . Nilai tersebut lebih kecil dari alpha (0,05), maka $\mathrm{H} 4$ diterima. Hasil penelitian menunjukan bahwa variabel profitabilitas berpengaruh terhadap audit delay.

Tingkat profitabilitas merupakan faktor penentu terhadap audit delay. Perusahaan yang memiliki tingkat profitabilitas besar akan cenderung untuk mempercepat proses auditnya dan sesegera mungkin menyampaikan laporan keuangannya karena hal ini merupakan kabar baik. Hasil penelitian ini sesuai dengan penelitian terdahulu (Amani \& Waluyo, 2016; Melati \& Sulistyawati, 2016; Saemargani \& Mustikawati, 2015) yang menemukan bahwa profitabilitas berpengaruh terhadap audit delay.

Berdasarkan hasil analisis regresi linear berganda dalam Tabel 2 menunjukan bahwa nilai signifikansi variabel solvabilitas sebesar 0.175 . Nilai tersebut lebih besar dari alpha $(0,05)$, maka H5 ditolak. Hasil penelitian

\section{KESIMPULAN DAN SARAN}

Penelitian ini $\begin{array}{r}\text { bertujuan } \\ \text { untuk }\end{array}$
faktor-faktor
mempengaruhi audit delay pada perusahaan yang tercatat di Bursa Efek Indonesia (BEI). Penelitian ini menemukan bahwa profitabilitas berpengaruh terhadap audit delay. Di sisi lain, penelitian ini tidak menemukan bahwa ukuran perusahaan, ukuran KAP, solvabilitas, dan rugi perusahaan berpengaruh berpengaruh terhadap audit delay.

\section{DAFTAR PUSTAKA}

Amani, F. A., \& Waluyo, I. (2016). Pengaruh Ukuran Perusahaan, Profitabilitas, Opini Audit, Dan Umur Perusahaan Terhadap Audit Delay (Studi Empiris Pada Perusahaan Property Dan Real Estate Yang Terdaftar Di Bursa Efek Indonesia Pada Tahun 2012-2014). Nominal, Barometer Riset Akuntansi Dan Manajemen, 5(1), 13-150.

Amani, F. A., \& Waluyo, I. (2016). Pengaruh Ukuran Perusahaan, Profitabilitas, Opini Audit, Dan Umur Perusahaan Terhadap Audit Delay (Studi Empiris Pada Perusahaan Property Dan Real Estate Yang Terdaftar Di Bursa Efek Indonesia Pada Tahun 2012-2014). Nominal, Barometer Riset Akuntansi Dan Manajemen, $5(1)$, $135-150$ https://doi.org/10.21831/nominal.v5i1.11482

Apriyani, N. N. (2015). Pengaruh Solvabilitas, Opini Auditor, menunjukan bahwa variabel Rugi Perusahaan tidak berpengaruh terhadap audit delay.

Hasil penelitian menunjukkan bahwa Rugi perusahaan tidak berpengaruh terhadap audit delay. Hal ini disebabkan prosedur audit perusahaan yang sama dalam mengungkapkan laporan keuangannya baik perusahaan mengalami laba ataupun perusahaan mengalami rugi. Jika ruang lingkup perusahaan yang diaudit dalam mengungkapkan laba lebih luas bisa saja akan mengalami audit delay yang lama dibandingkan pengungkapan rugi pada perusahaan dengan ruang lingkup audit yang lebih sempit. Hal lain yang diperkirakan adalah rugi yang masih dianggap wajar oleh auditor sehingga tidak berpengaruh terhadap going concern perusahaan. Hasil penelitian ini sesuai dengan penelitian terdahulu (Arofah et al., 2017; Fiatmoko \& Anisykurlillah, 2015; Surbakti \& Aginta, 2019) yang menyatakan bahwa laba/rugi perusahaan tidak berpengaruh terhadap audit delay

Keterbatasan penelitian ini hanya memeriksa perusahaan yang bergerak di industri perdagangan, jasa dan investasi dengan menggunakan dua periode pengamatan. Oleh karena itu, penelitian selanjutnya disarankan untuk menambah sampel dengan mengikutsertakan industri yang lain dan menggunakan periode pengamatan yang lebih dari 2 tahun.

Ukuran Kap, Dan Komite Audit Terhadap Audit Delay. Jurnal Akuntansi Dan Sistem Teknologi Informasi, 11, 169-177.

Arofah, U., Astuti, D. S. P., \& Harimurti, F. (2017). Ukuran Perusahaan Sebagai Pemoderasi Pengaruh Kepemilikan Publik Komite Audit Dan Laba Rugi Terhadap Audit Delay. Jurnal Akuntansi Dan Sistem Teknologi Informasi, 13(2), 297-305.

CNBC. (2019). Perhatian! 24 Emiten Ini Kena Sanksi BEI, Kenapa?

Fiatmoko, A. L., \& Anisykurlillah, I. (2015). Faktor-Faktor Yang Berpengaruh Terhadap Audit Delay Pada Perusahaan Perbankan. Accounting Analysis Journal, 4(1), 1-10.

Haryani, J., \& Wiratmaja, I. D. N. (2014). Pengaruh Ukuran Perusahaan, Komite Audit, Penerapan Dan International Financial Reporting Standards Dan Kepemilikan Publik Pada Audit Delay. E-Jurnal 
Akuntansi Universitas Udayana, 6(1), 63-78.

Juanita, G., \& Satwiko, R. (2012). Pengaruh Ukuran Kantor Akuntan Publik, Kepemilikan, Laba Rugi, Profitabilitas dan Solvabilitas terhadap Audit Report Lag. Jurnal Bisnis Dan Akuntansi, 14(1), 31-40.

Kartika, A. (2009). Faktor-Faktor yang Mempengaruhi Audit Delay di Indonesia (Studi Empiris pada PerusahaanPerusahaan LQ 45 yang Terdaftar di Bursa Efek Jakarta). Jurnal Bisnis Dan Ekonomi, 16(1), 1-17.

Kasmir. (2008). Analisis Laporan Keuangan. PT Raja Grafindo Persada.

Melati, L., \& Sulistyawati, A. I. (2016). Audit Delay Pada Perusahaan Pertambangan: Analisis Dan Faktor-Faktor Penentunya. Jurnal Akuntansi Indonesia, 5(1), 37. https://doi.org/10.30659/jai.5.1.37-56

Pratama, H. G. (2015). Pengaruh Ukuran KAP,Profitabilitas, Komite Audit, Ukuran Perusahaan, dan Leverage Terhadap Audit Delay Pada Perusahaan Manufaktur di BEI Tahun 2009-2013. Jurnal Akuntansi AKUNESA, $3(2), 1-26$.
Regilia. (2018). Pengaruh Ukuran Perusahaan, Solvabilitas, Laba(Rugi) Operasi, Dan Opini Auditor Terhadap Audit Delay. 5(1), 21-43.

Saemargani, F. I., \& Mustikawati, R. I. (2015). Pengaruh Ukuran Perusahaan, Profitabilitas, Solvabilitas Dan Opini Auditor Terhadap Audit Delay. Jurnal Analisa Akuntansi Dan Perpajakan, IV(2), 1-15. https://doi.org/10.25139/jaap.v2i2.1397

Surbakti, H. S. B., \& Aginta, W. (2019). Faktor-Faktor Yang Mempengaruhi Audit Delay Pada Perusahaan Lq45 Yang Terdaftar Di Bursa Efek Indonesia. Jurnal Akuntansi Dan Bisnis, 9(1), 181-190.

Syah, E. S. M. (2017). The effects of solvability, public ownership, auditor switching and holding company toward audit delay. Jom Fekon, 4(1), 1801-1812.

Trisnawati, E., \& Charistine. (2008). Pengaruh Opini Audit, Rasio Profitabilitas, Solvabilitas, Dan Ukuran Kap Terhadap Audit Delay. Jurnal Akuntansi, 8(1), 107126. 